\title{
Biafra and the Aesthetics of Closure in the Third Generation Nigerian Novel
}

\author{
Madhu Krishnan \\ The University of Nottingham,UK
}

\begin{abstract}
This paper examines the role of closure, or the lack thereof, in four contemporary Nigerian novels. Representative of the third wave of Nigerian literature, these narratives each deals with themes of trauma, identity and community affiliation in postcolonial Africa, highlighting the fractured and displaced nation-state as the site of a radical aporia between individual fulfillment and communal harmony. This article postulates that the lack of closure on the level of thematic content and characterization in these novels is an aesthetic condition of third generation Nigerian literature as it strives to narrativize the openness and undecidability of the postcolonial condition and the fundamental instability of history and identity-formation in contemporary Africa.
\end{abstract}

Keywords: closure, narrative, Nigeria, Biafra

Contrary to normative wisdom in postcolonial literary and cultural studies, the rise of diffused production, or the formal organization of globalized capitalism in the late 20th century, could not result in the fragmentation of the Nigerian national imaginary because the work of inventing that nation, which started during the independence struggle, was never completed. The nation to be fragmented is yet to be created (Adéèkó 12).

Closure is one of the most widely studied areas in narrative theory. Peter Rabinowitz (Before Reading) has explained the importance of closure as one where, because of its privileged position in narrative, readers and writings imbue endings with extra significance. This need for closure in literature has been called the very purpose of reading (Brooks 92). In his introduction to narrative theory, Abbott expresses closure as the narrative effect which 'has to do with a broad range of expectations and uncertainties that arise during the course of a narrative and that part of us, at least, hopes to resolve, or close' (53). While closure is not obligatory to a narrative, and, certainly, many well-known narratives end without it, closure is an important part of the satisfaction of literature and the way in which individuals are able to organize stories as coherent and meaningful. Western literature, on the whole, tends to follow Rabinowitz's rules of coherence, in providing its stories with a sense of completeness, importance and finality through closure. Endings are not necessarily a narrative focus but instead serve the important function of 'scaffold[ing] our retrospective interpretation of the book' ("Reading Beginnings and Endings" 303) because 'there is also a widely 
applicably interpretive convention that permits us to read [the ending] in a special way, as a conclusion, as a summing up of the work's meaning' (Ibid. 304). Closure and narrative endings, then, are what shed light, retrospectively, on the text as a whole, allowing it to mean and resonate.

In classical terms, closure creates the narrative text as a self-contained unit (Barthes 33). Because the narrative must end, the narrativization of events allow them to become 'endurable because finite' (Herman 173), enabling the 'desire to have real events display the coherence, integrity, fullness, and closure of an image of life that is and can only be imaginary' (White 284). By creating the illusion that any event, no matter how traumatic, has a definitive end, narrative becomes a means for individuals to quickly process and progress from the past and its disturbances. Narrative fiction 'may by default have become the only effective means to digest the poison of the past, and to slowly heal from within the damage that has been done' (Hawley 16), in large part because of the catharsis of closure. In this paper, narratives which lack closure will be examined to discover what happens when narratives end with conflicts hung in stasis and characters suspended in time. This paper will argue that flouting the traditional conception of closure allows these narratives to block any simple resolution to the past and its traumas and instead forces a lasting engagement with history and its effects, mirroring in the aesthetics of (non)closure the thematic importance of the text.

\section{Biafra and the third generation Nigerian novel}

From 1967 to 1970, the Nigerian Civil War, often called the Biafran War, raged across the southeast of the West African nation. This war was notable for a variety of reasons: through the war, the West first saw the now-familiar image of the starving child with kwashiorkor; Médicins Sans Frontiers was founded in part as a response to Nigerian aid-blockages; and the war, in many ways, became a staging of postcolonial conflict between the former imperial powers in Africa, England and France. Perhaps more notable still were the questions the war begged about national identity, African agency and the right to demark nation-states and allegiances on the continent in the wake of colonial withdrawal.

In recent years, several novels chronicling these years have risen to notoriety in the West. These novels, as part of what has been broadly termed third generation Nigerian literature, in many ways mark the entrance of Biafra and the Biafran War into transnational memory. Citing Appiah, Etsy has characterized the earlier generations of Nigerian literature, saying that 'the largely realist texts of the first wave project a version of Africa's "usable past" ...By contrast, the second-wave works ... distrust nationalism and disrupt realism' (24-25). As noted by Nwakanma, for decades following the war's end, little, if any, literary writing dealt with the subject (7); perhaps the memory was 
too close, as families torn apart and communities dislocated and destroyed sought to rebuild. Today, the third generation of Nigerian writers has returned to the wider thematics of first generation literature, but with a view to questioning the assumptions earlier literature made about Africa, Nigeria and the validity of historical realism when confronting the past. As such, for the first time, the Biafra question and legacy of war has been widely considered in literature. Third generation literature, taken as an example of one tradition in contemporary Nigerian fiction, represents the striving of a younger generation to remember the trauma of the past and to forge a sense of kinship and identity through their shared connection in community. With the passage of time, the resurgence of Biafra in Nigerian literature marks the importance of the period to contemporary identity formation and underlines its lasting effects on national identity and the national imaginary, particularly relevant at a time when Biafran nationalism is returning to the forefront of Nigerian politics.

This paper will consider four novels in particular: Chris Abani's GraceLand, Chimamanda Ngozi Adichie's Half of a Yellow Sun, Uzodinma Iweala's Beasts of No Nation and Helon Habila's Measuring Time. Each of these four novelists has spent considerable time in the United States' academia either as students or instructors, and, of the four, only Adichie currently resides in Nigeria. All four novelists have received critical praise and attention in the United States and Europe: Abani has won the Hemingway/PEN Prize, Adichie the Orange Prize for Fiction, Iweala the Sue Kaufman prize and Habila the Caine African Writers' Prize, amongst numerous others. While Adichie and Iweala's novels directly address the Civil War, Abani and Habila use it as a shadow or backdrop to their novels. In dealing with their thematic content, all four novels consider the daily lives of individuals in post-independence Nigeria over the broader machinations of politicians and armies. Together, the four novels represent a turn in contemporary Nigerian fiction, as the current generation of writers and artists seek to make sense of the present tensions and ethnic strife in their country through an interrogation of the past, putting special significance on the human scale of trauma and the individually negotiated state of belonging and community engagement. These narratives enact the task of literature set by Biyi Bandele Thomas, 'to kind of open those wounds [from the Civil War] and look at things, study them very carefully' (quoted in Bryce 58). The novels considered here all contribute to this sort of critical examination and open study of the past. Particularly, the workings of closure, or lack thereof, in these narratives exemplify this struggle through the aesthetic workings of the third generation Nigerian novel.

\section{GraceLand}

GraceLand tells the story of Elvis, a 16 year old occasional street performer struggling to make a living in Lagos. Following the death of his mother 
and his father's political losses, Elvis and his father are forced to leave their comfortable life in their ancestral village for the slums of Lagos. While Elvis's father, Sunday, remarries and drinks away his days, Elvis is left attempting to scramble some form of survival out of the unforgiving city. The narrative alternates between Elvis's life in Lagos and earlier scenes in Afikpo, his ancestral home. The narrative indicates that these scenes are memories which haunt Elvis as he struggles in Lagos. They recollect traumas Elvis has long repressed: his cousin Innocent, mad since his return from the Biafran War where he had been conscripted as a boy soldier, is paid by Elvis's father and uncle to kill another cousin, Godfrey (Abani 151, 174); his cousin and closest confidante, Efua is raped and abused by her father (Ibid. 64, 144), who eventually rapes Elvis as well (Ibid. 198). As Elvis attempts to find a way to make a living in Lagos through his passion for dancing, these memories taint his existence with greater force. After being arrested and tortured by the government for offending a police chief at a nightclub (Ibid. 288), Elvis eventually finds himself living on the street with the beggar children of the city (Ibid. 307). Finally, seemingly near death, Elvis finds a way out through his friend Redemption who gives Elvis his mysteriously procured visa to the United States (Ibid. 317) where Elvis's aunt Felicia now lives.

At the novel's conclusion, Elvis sits at the airport, awaiting his departure: 'He knew that what he thought he was leaving behind wasn't much, and after all, his aunt Felicia was in America. No, what he was leaving had nothing to do with quantity; nor, in spite of Redemption's protestations, did it have to do with quality. This was something else, something essential' (Ibid. 318-319). Even at his moment of departure, Elvis is unable to thematize or rationalize what has happened to him. He waits at the airport with no plans or sense of how to feel or process what is happening. As his flight is called, Elvis thinks of his lost cousins, his dead father and his abandoned friends (Ibid. 321), coming to no conclusions about any of them. The novel ends as Elvis, by the assumed name on his visa, is called to his boarding gate:

"Redemption," the airline clerk called.

Elvis, still unfamiliar with his new name, did not respond.

"Redemption!" the clerk called louder.

Elvis stepped forward and spoke.

"Yes, this is Redemption." (Ibid. 321).

While, symbolically, it is tempting to see the narrative ending, as it says, with redemption, nothing in the narrative proper points to this interpretation. Elvis, in fact, redeems no one; he simply leaves, or attempts to.

Critics have interpreted the ending of GraceLand as one in which Elvis chooses himself and individuality over the tumultuous nation-state, claiming that 
'The flight to America ... replaces the recuperative escape to the unspoiled village, the narrative strategy commonly used in earlier stories of the nation to protect characters against the ravaging propensities of the metropolitan seats of deadly power play' (Adéèkó 17). What this view fails to consider is the ambiguity of Elvis's position; it remains unsaid whether he makes it past the boarding gate check point and on to the plane and, more saliently, a departure for America does not imply a happy, or even conclusive, ending. Elvis himself asks, in the novel, "When did we start thinking of America as a life plan?" (Abani 318), indicating the general tenacity of the American dream and the strong likelihood that, for a character of low socioeconomic status like Elvis, a fresh start in America would not imply success at all any more than any other dream.

For a novel which is often dismissed as a coming-of-age story (c.f. Hron) or a postcolonial version of the American Dream (c.f. Adéèkó), the lack of closure at the end of the novel is often overlooked. In fact, a focus on this lack of closure points out the need for a refocusing on the entire narrative and its meaning. Because endings 'force us to return to the beginnings of the works we've just completed ... by (and after) indirectly revealing shadow narratives that have been lying latent' (Reising 323), the lack of closure in GraceLand points to the instability and uncertainty of existence in the postcolony, an instability born from its rupture with the past. In GraceLand, this shadow narrative is about the very ambiguity of existence itself and the inability to negotiate true closure within human experience, continually deferred.

\section{Half of a Yellow Sun}

Robert Young has suggested that to produce closure any text must occlude its own history (102). The refusal to turn its back on history as a completed action no longer connected to the present may explain the lack of closure in Half of a Yellow Sun. The narrative, intertwining the lives of several individuals before and during the Biafran war, centers on the household of Odenigbo and Olanna, two professors at Nsukka University in Igboland. Amongst their circle are writers, poets and intellectuals all involved in the shaping of postindependence Nigeria, including Richard, a white Englishman-turned-Biafran who begins a relationship with Olanna's twin sister, Kainene, and Odenigbo's houseboy, Ugwu. The narrative alternates between the outset of the war and its conclusion, slowly building up an intertwining sense of the inherently dialogic nature of causes and effects and the interconnections that define seemingly disparate events, people and places, ending shortly after the war has ended and Biafra has lost. During the resulting aid blockade, Kainene, who runs a refugee center, leaves to cross the provisional borders to trade for supplies for the camp, what is locally known as afia attack (Adichie 403-405). Her departure is presented as nothing unusual in the course of a narrative filled with displacements, internal migrancy and unsettling. Yet, at the narrative's close, 
Kainene has not returned. Olanna and Richard's attempts to search for her turn up no clues (lbid. 407). No body is found. As the narrative ends, nothing more is said of what happened to Kainene, if she is alive and what befell her on afia attack.

Oates claims that Half of a Yellow Sun 'creates a dialectic between the prewar intellectual freedom of the privileged academic environment that characters enjoyed and the dehumanization of war' (164). This dialectic is enacted primarily through the characters: Ugwu's growth into the scribe of Biafra; Odenigbo and Olanna's uneasy development into a family; Richard and Kainene's deepening relationship and symbiotic need for each other; Olanna and Kainene's fragile bond as sisters united in a new nation. Crucial to the dialectic progression are the human interactions which, in aggregate, create the history of the nation. The removal of one of the players, Kainene, with no warning or explanation throws the dialectic off balance and irretrievably blocks its progression. If, indeed, the narrative is a dialectic movement between the two eras, it is a dialectic which is never resolved; synthesis is unattainable within the text because one of its elements disappears. Rabinowitz (Before Reading) claims that endings are prefigured by their beginnings. In Half of a Yellow Sun, the unfinished dialectic precludes this. The progression of the text is halted and left open and unfinishable, resistant to its own totality. The constant deferral is seen in the open-ended fate of Kainene, who remains inassimilable to the text. By forcing the text to remain open and unsolvable, questions of history, identity and community asked in the text remain in a constant state of negotiation.

\section{Measuring Time}

Mamo is the protagonist and focalizer of Measuring Time. One of two twins whose mother has died at their birth, Mamo suffers from sickle-cell anemia and, because of his infirmity, is forced to stay behind with his wealthy, ambitious and unloving father while his twin brother, LaMamo, runs away from home to be a mercenary in Chad, Libya and Liberia. Inspired by their uncle, a war veteran mysteriously returning seven years after the end of the Biafran War, the boys dream that the soldier's life will lead to fame and notoriety, an interaction which shapes the two brothers' paths in life for the remainder of the novel.

In many ways, Measuring Time marks a more traditional narrative structure than the previous two novels. The novel has been referred to as 'extend[ing] the boundaries of the Nigerian novel' (Adesanmi and Dunton viii) in its scope and range. The majority of its major storylines find some form of closure: Mamo and LaMamo's emotionally remote father dies following his failures in politics and in life (Habila 220); the corrupt Mai Mamo finds himself working for is exposed and justice is delivered (Ibid. 350); LaMamo eventually returns home from his years of war and dies in the struggle against the Mai after 
reuniting with his brother (Ibid. 354). This closure, however, only works on the narrative's surface level. On a deeper level, the narrative of Measuring Time is not about village politics or the two brothers. Instead, the narrative focuses on Mamo as the twin who is left behind. Given the significance of twins in Nigerian culture (Menkiti 123), his status as separated from his twin and left to negotiate some form of identity alone is significant. For a while, Mamo is able to do this through his relationship with Zara, a childhood acquaintance, metonymically standing in for his missing spirit twin, and his aspirations as a writer, and these two strands of Mamo's existence mark the deeper movement of the narrative. Yet, at the end of the novel, Mamo's relationship with Zara is ambiguous, as their romantic entanglement has ended, and she has left for South Africa with another man (Habila 226-228). Towards the end of the narrative she returns, suffering from madness and depression. Mamo attempts to see her but is finally unable to cope with the situation (Ibid. 376). The narrative ends with no indication of whether Mamo would ever see Zara again and whether their relationship would continue. In a hopeful burst, he imagines himself able to see Zara again: 'He resolved to go to Zara and this time no one would deny him access to her. He would reason with the mother, he would tell her how much he loved Zara' (Ibid. 381). Despite his resolve, Mamo, within the narrative, never reaches Zara's house and never attempts to see her again. Instead, she becomes his hypothetical interlocutor: 'This is what he would tell Zara-it was all about survival, about bending a little so as not to totally break. He was sure she'd understand' (Ibid. 382). Zara, for Mamo, remains an idea rather than a relationship acted out and his metonymic desire for the other half to his self is left unresolved.

Mamo's status as writer is left further ambivalent. While critics have claimed that 'grown-up griot Mamo Lamang reclaims stories, tradition, and history in his rural village' (Hron 44), this action occurs outside the boundaries of the text and is not indicated as anything more than a desire or fantasy within the diegesis. Though the narrative continually hints towards his becoming the biographer of Keti, repeatedly using the formula 'When Mamo wrote his biography of...' to introduce new chapters and characters, in the narrative proper this never occurs; the biography he is hired to write for the Mai is never written and the story of Keti is never told. From these two important standpoints, then, Measuring Time lacks a sense of closure, particularly noticeable given its format as a Bildungsroman following Mamo's unlikely existence. Jameson describes narrative closure as an issue 'of the relationship of a narrative text to futurity and to some collective project yet to come' (Jameson 77). Under this formulation, the narrative may drive the destiny of the nation. For Mamo, however, the future is forever uncertain as he spends most of his days waiting: for his brother, for Zara, for something to write about, for his sickle-cell disease to kill him. Because the character is suspended in stasis, the lack of closure of the narrative is the only possible endings for the text. 


\section{Beasts of No Nation}

Beasts of No Nation is, in many ways, an easier narrative case. The narrative itself is unusual amongst these four novels. While the other three novels roughly fall into the category of historical realism, working, as they do, with historical events, large scale plots and settings and grand, if unfinished, character arcs, Beast of No Nation is a relatively short narrative told in the first person by a boy solider of about eight years old. The child, called Agu, has been conscripted as part of a rebel army in an unnamed African war that, contextually, is possibly recognizable as the Biafran War. The narrative is disjointed, told through the haze of current trauma and fragmented memories of happier times. Agu recounts his earlier childhood, love of books and reading, happiness at school and happy family life, eventually torn apart by the war. He describes his father's murder before his eyes (Iweala 72) and his mother and sister's disappearance (lbid. 69). In the war, the child-narrator describes his initial fear and his participation in rape, looting and murder (Ibid. 47-51) as well as his own violation in rape and abuse (Ibid. 84-87). The novel ends abruptly. Agu watches as his commander is murdered by one of his own men and is set free from conscription along with the other soldiers. The narrative ends with Agu in a rehabilitation camp, undergoing therapy with an American counselor.

One critic has described the role of children in Nigerian literature as 'always intrinsically enmeshed in a cultural and social community, and thus must somehow negotiate ethnic identity or social status in the course of the narrative' (Hron 29). In Beasts of No Nation, this negotiation is never realized. Agu is still alone at the narrative's end, with no indication of a reunion with his lost family; his village is but a distant memory and his only regular communication is with his American therapist. The lines of kinship, ethnicity and community have been severed and no closure is given on whether they will be rebuilt or whether new lines will be constructed in their place.

The narrative of Beast of No Nation ends with the following lines:

'When I am saying all of this, she is just looking at me and I am seeing water in her eye. So I am saying to her if I am telling this to you it will be making you think that I am some sort of beast or devil. Amy is never saying anything when I am saying this, but the water is shining in her eye. And I am saying to her, fine. I am all of this thing. I am all of this thing, but I am also having mother once, and she is loving me' (Iweala 141-142).

This conclusion has been described as one whose end is notable for 'the lack of an easy and comforting moral' (Street 160). Through the narrative, Agu has killed, raped, been raped and descended into the madness of war, forever destroying the innocence of childhood. Throughout, relief comes only when Agu 
recalls his brief days in school and his pride at learning and reading and enjoyment within his family home, but this proves no match for the war. Agu's childhood enjoyments are gone and the narrative ends with no indication of whether he will ever reclaim them. In the story, 'language, or rather, the lack of language, plays an important role ... as the author explores a child's ability to articulate or respond to the terror and trauma of war' (Hron 40), and, as indicated by the ending, Agu's continued ability to use language to negotiate what has happened to him is left ambivalent and ambiguous.

\section{Conclusion: towards an open past}

In many ways, the act of narrative closure can be seen as the narrative's folding in on itself, sealing itself into a comprehensible whole. With closure comes fullness and completion. Closure creates a logic and sensibility to the disparate and chaotic events of narrative and, when it is missing, it signals the significance of the narrative while enclosing the characters, events and themes of the narrative in a coherent whole. In her discussion of three women's texts, Spivak identifies certain textual elements which 'cannot be contained by the text' (258). Literally, these characters are beyond the scope of the narrative and exceed its possibility. This, too, is seen in the narratives under analysis in this paper. In situations of extreme instability and constant flux, the individuals portrayed exceed the workings of the text, seeping out of it past the point of containment, represented by the text's inability to provide them with closure. By exceeding the text in this way, these narratives illustrate the 'persuasive power of the literary imagination [that] renders accessible the wisdom of that which might be, literally, beyond belief' (Eze 29).

By undermining the traditional rules of coherence and closure, the thirdgeneration Nigerian narratives under examination here expose the inherent falsity of the notions of completeness, logic and sensibility. Narratological closures make ideas like modernity, colonialism, history and nationalism seem homogeneous and closed (Chakrabarty 384). In a nation repeatedly violated by colonialism, sectarian violence, ethnic conflict and military intervention after military intervention, the notion of logic through closure remains elusive, as the nation itself remains dynamic, in flux and in a constant state of death and rebirth. If closure is, in fact, the means by which readers and writers find a sense of logic and stability to narrative, then the absence of closure in these novels is of little surprise. As Abbott has noted, 'one very plausible possibility is that the representation of conflict in narrative provides a way for culture to talk to itself about, and possibly resolve, conflicts that threaten to fracture it (or at least make living difficult)' (51). As we have seen, the conflicts portrayed in third generation Nigerian novels are not ones which are easily solved or swept away. While 'Nigeria's political history reflects a deep search for the coherent meaning of nation, and its context of affiliation or belonging, has been characterized by the 
demands to construct a coherent narrative to reflect this aspiration' (Nwakanma 2 ), the refusal to provide such a constructed coherence works as a sign of resistance and openness. By refusing the narrative compulsion of closure and tidy endings, these narratives and their representation of individuals and conflicts highlight the importance of continued negotiation and interrogation necessary in the postcolonial condition.

\section{Works Cited}

Abani, Chris. GraceLand. New York: Picador, 2004. Print.

Abbott, H. Porter. The Cambridge Introduction to Narrative. Cambridge, UK: Cambridge University Press, 2002. Print

Adéèkó, Adélékè. "Power Shift: America in the New Nigerian Imagination." Global South 2.2 (2008): 10-30. Print.

Adesami, Pius and Dunton, Chris. "Everything Good is Raining: Provisional Notes on the Nigerian Novel of the Third Generation." Research in African Literatures 39.2 (2008): vii - xii. Print.

Adichie, Chimamanda Ngozi. Half of a Yellow Sun. London: Harper Perennial, 2006. Print.

Barthes, Roland. "Theory of the Text." Untying the Text: A Post-Structuralist Reader. Ed. Robert Young. London: Routledge, 1981. 31-47. Print.

Brooks, Peter. Reading for the Plot: Design and Intention in Narrative. Cambridge, MA: Harvard University Press, 1984. Print.

Bryce, Jane. "'Half and Half Children': Third-Generation Women Writers and the New Nigerian Novel." Research in African Literatures 39.2 (2008): 49-67. Print.

Chakrabarty, Dipesh. "The Difference—Deferral of a Colonial Modernity: Public Debates on Domesticity in British Bengal", Tensions of Empire: Colonial Culture in a Bourgeois World. Eds. Frederic Cooper and Ann Stoler. Berkeley, CA: University of California Press, 1997. 373-405. Print.

Etsy, Joshua D. "Excremental Postcolonialism." Contemporary Literature 40.1 (1999): 22-59. Print.

Eze, Emmanuel Chukwudi "Language and Time in Postcolonial Experience." Research in African Literatures 39.1 (2008): 24-47. Print.

Habila, Helon. Measuring Time. New York, NY: W. W. Norton and Country, 2007. Print.

Hawley, John C. "Biafra as Heritage and Symbol: Adichie, Mbachu, and Iweala." Research in African Literatures 39.2 (2008): 15-26. Print.

Herman, David. "Stories as a Tool for Thinking." Narrative Theory and the Cognitive Sciences. Ed. David Herman. Stanford, CA: CSLI Publications, 2003. 163-192. Print.

Hron, Madelaine. "Ora na-azu nwa: The Figure of the Child in Third-Generation Nigerian Novels", Research in African Literatures 39.2 (2008): 27-48. Print

Iweala, Uzodinma. Beasts of No Nation. New York, NY: Harper Perennial, 2006. Print. Jameson, Frederic. "Third-World Literature in the Era of Multinational Capitalism." Social Text 15 (1986): 65-88. Print.

Menkiti, Ifeanyi. "Physical and Metaphysical Understanding." Philosophy: New and 
Traditional Perspectives. Ed. Lee M. Brown. New York: Oxford Univeristy Press, 2004. 107-135. Print.

Nwakanma, Obi. "Metonymic Eruptions: Igbo Novelists, the Narrative of the Nation, and New Developments in the Contemporary Nigerian Novel." Research in African Literatures 39.2 (2008): 1-14. Print.

Oates, Nathan. "Political stories: The Individual in Contemporary Fiction." The Missouri Review 3 (2007): 156-171. Print.

Rabinowitz, Peter. Before Reading: Narrative Conventions and the Politics of Interpretation. Columbus, OH: Ohio State University Press, 1987. Print.

Rabinowitz, Peter. "Reading Beginnings and Endings." Narrative Dynamics: Essays on Time, Plot, Closure, and Frames. Ed. Brian Richardson. Columbus, $\mathrm{OH}$ : Ohio State University Press, 2002. 300-313. Print.

Reising, Russell. "Loose Ends: Aesthetic Closure and Social Crisis." Narrative Dynamics: Essays on Time, Plot, Closure, and Frames. Ed. Brian Richardson. Columbus, OH: Ohio State University Press, 2002. 314-328. Print.

Spivak, Gayatri Chakravorty. "Three Women's Texts and a Critique of Imperialism." Critical Inquiry 12.1 (1985): 243-261. Print.

Street, Steve. "Beasts of No Nation." The Missouri Review 29.2 (2006): 160-161. Print.

White, Hayden. "The Value of Narrativity in the Representation of Reality." Narratology. Eds. Susana Onega and Jose Angel Garcia Landa. London: Longman, 1996. 273-285. Print.

Young, Robert. White Mythologies. Abingdon, Oxon: Routledge, 2004. Print.

Madhu Krishnan is a PhD candidate in University of Nottingham, UK.

Email: aexmk6@nottingham.ac.uk 